Ольга НЕСТЕРЕНКО, orcid.org/0000-0003-1774-456X кандидат фізико-математичних наук, дочент кафедри вищзої математики, завідувачка кафедри прикладної фізики та вищої математики Київського національного університету технологій та дизайну (Київ, Украӥна) Nesterenkoolha@gmail.com

\title{
ПРОФЕСІЙНО ЗОРІЕНТОВАНІ ЗАВДАННЯ ЯК ЗАСІБ РЕАЛІЗАЦІЇ ПРИНЦИПУ ПРОФЕСІЙНОЇ СПРЯМОВАНОСТІ НАВЧАННЯ МАТЕМАТИКИ В ЗАКЛАДАХ ВИЩОЇ ОСВІТИ
}

\begin{abstract}
У сучасних умовах компетентнісний підхід у навчанні диктує необхідність імплементації приниипу профе-
\end{abstract} сійної спрямованості навчання, основне завдання якого - усунути суперечності між теоретичним характером досліджуваних дисциплін і практичним умінням застосовувати ціі знання у професійній діяльності. Встановлено, щсо більшість навчальних видань із математики, рекомендованих для студентів закладів вищої освіти, обмежуються стандартними завданнями прикладного змісту у вивченні математики і не мають повного переліку професійно орієнтованих завдань. Поняття «професійно зорієнтовані завдання» є видовим стосовно більш загального поняття - «прикладна задача» як завдання, окреслене поза математикою та розв'язуване математичними засобами.

На основі аналізу науково-методичної літератури, присвяченої застосуванню професійно зорієнтованих завдань у навчанні математики, уточнено поняття «професійно зорієнтована завдання» як завдання, щзо відображають абстрактну модель деякої реальної ситуацї, щуо виникає у професійній діяльності, яке вирішується математичними методами або методами, застосовуваними у професійній діяльності майбутніх фахівців, $i$ сприяє розвитку особистості майбутнього фахівия.

У закладах вищеї освіти виокремлено три типи професійно зорієнтованих завдань: власне професійно зорієнтовані завдання, завдання для виконання лабораторних робіт, професійно зорієнтовані проєкти. Кожен тип завдання використовується в певній формі організації освітнього процесу із застосуванням специфічних методів $і$ засобів навчання. Кожен тип завдання виконує власні педагогічні функиіі, має певні механізми впливу на навчальну мотивацію $i$ засвоєння математичних знань $і$ умінь студентів. Наведено типологію завдань: змістові та прочесуальні. Окреслено співвідношення між поняттями «професійно зорієнтовані завдання» $i$ «прикладна задача» як співвідношення «вид - рід». Визначено специфічну властивість професійно зорієнтованих завдань як здатність виконувати різній ролі для різного контингенту студентів: те саме завдання може бути лише прикладним для однієї категорії і стає професійно зорієнтованим для іншої категорії студентів.

Ключові слова: професійно зорієнтовані завдання, принции професійної спрямованості, заклади вищої освіти, професійно зорієнтовані проєкти.

Olha NESTERENKO,
orcid.org/0000-0003-1774-456X

Candidate of Physical and Mathematical Sciences,

Associate Professor at the Department of the Higher Mathematics, Head of the Department of Applied Physics and Higher Mathematics Kyiv National University of Technologies and Design (Kyiv,Ukraine) Nesterenkoolha@gmail.com

\section{PROFESSIONALLY ORIENTED TASKS AS A WAY \\ OF APPLYING THE PROFESSIONAL ORIENTATION PRINCIPLE OF TEACHING MATHEMATICS IN HIGHER EDUCATION INSTITUTIONS}

In modern conditions, the competence approach in education defines the necessity to implement the principle of professional orientation in education, the main task of which is to resolve the contradictions between the theoretical nature of the disciplines and the ability to practically apply the received knowledge in professional activities. It has been established that most educational publications in mathematics recommended for students of higher education institutions (HEIs) are limited to standard tasks of applied content in the study of mathematics, with no complete list of professionallyoriented tasks. The concept of professionally oriented tasks is a specific segment of a more general concept of applied task, which is outlined outside of mathematics and solved by mathematical means. 
Based on the analysis of scientific and methodological literature on the use of professionally oriented tasks in teaching mathematics, the concept of "professionally oriented task" could be defined as a task that reflects an abstract model of a real situation in professional activities, solved by mathematical methods or methods used in professional activity of future specialists, helping their personal development as well.

There are three types of professionally oriented tasks in higher education institutions: professionally oriented tasks themselves, laboratory tasks and professionally oriented projects. Each type of tasks is used in a certain form of organization of the teaching process, having its own specific methods and teaching aids. Each type of tasks has its own pedagogical function and certain mechanisms of influence on the learning motivation and assimilation of mathematical knowledge and skills of students. The tasks are divided into substantive and procedural. The connection between the concepts of "professionally oriented tasks" and "applied task" is defined as a connection of a narrower concept to a more general one. The specific property of professionally oriented tasks is defined as the ability to act in different roles for different group of students: the same task can only be viewed as an applied task for one category and for another one it might be considered a professionally-oriented task.

Key words: professionally oriented tasks, professional orientation principle, of higher education institutions, professionally oriented projects.

Постановка проблеми. Протягом останнього десятиліття в Україні відбувається модернізація системи вищої освіти, основна мета якої - підвищення якості підготовки фахівців. Провідними професійно значущими якостями фахівця в сучасному суспільстві $€$ його професійна компетентність, конкурентоспроможність, здатність до ефективного вирішення завдань у широкому колі соціальних, професійних і життєвих ситуацій. 3 огляду на це особлива роль відводиться оновленню змісту професійної освіти 3 метою узгодження іiі з вимогами суспільства і ринку праці, переосмислення цілей і результатів освіти.

Водночас без фундаментальної математичної підготовки неможлива сучасна якісна вища освіта. Математика сьогодні - це не лише потужний динамічний пласт людських знань (елемент загальної культури людства), засіб компактизації інформації та засіб розвитку психічних якостей людини, а й метод пізнання навколишньої дійсності, засіб вирішення життєво важливих практичних та професійних завдань (Копетчук, 2009: 470-483).

Математика $є$ основою вищої освіти й у практичній діяльності фахівця повинна допомагати вирішувати професійні завдання. Часто в системі підготовки фахівця певного профілю курс вищої математики недостатньо підпорядковується концептуальним засадам формування спеціаліста. Однією із проблем якості освіти є недостатня реалізація на практиці принципу професійної спрямованості математичних курсів. Парадоксально виглядає ситуація, коли заклади вищої освіти різних профілів користуються тими самими збірниками завдань, у яких блок прикладних задач відсутній взагалі або мізерний. Не менш гостро стоїть проблема змісту математичної освіти, який мав би бути строго структурованим за функціями та цілями. Уважаємо, що професійна спрямованість може бути значно посиленою шляхом використання професійно зорієнтованих завдань.
Аналіз досліджень. Проблема реалізації прикладної спрямованості завжди залишається в полі зору науковців-методистів (О. Александров, Г. Бевз, С. Варданян, Б. Гнєденко, О. Дубинчук, Г. Дутка, А. Колмогоров, Ю. Колягін, В. Фірсов та ін.). Питання професійно спрямованого навчання в закладах вищої освіти (далі - ЗВО) та різноманітні питання навчання математики у ЗВО розглядали у своїх дослідженнях Е. Вентцель, В. Клочко, Т. Крилова, А. Мишкіс, Н. Морзе, Г. Морозов, 3. Слєпкань, І. Тесленко, В. Швець та інші. Однак здебільшого відомі наукові пошуки (О. Богомолов, М. Бобнєва, Г. Іосилевич, П. Лєбєдєв, М. Позін, В. Стреляєв та інші) мають загальну технічну спрямованість і не відображають специфіки конкретних напрямів та спеціальностей або стосуються спеціальних дисциплін (С. Артюх, В. Бєлікова, Е. Бєлова, О. Жильцов, Г. Ізюмська, О. Коваленко, Г. Торбін та інші). Проблеми, пов'язані з методикою навчання математики у вищій школі, відображені в дослідженнях Т. Крилової, Л. Новицької, Л. Панченко, О. Семенихіної, О. Фомкіної та інших). Однак донині немає досліджень, присвячених системному підходу до професійно зорієнтованого навчання математики в закладах вищої освіти, зокрема й використання принципу професійної спрямованості.

Мета статті полягає у виявленні й обгрунтуванні особливостей професійно зорієнтованого навчання математики в закладах вищої освіти на основі теоретичного аналізу науково-педагогічних досліджень; уточненні змісту базових понять дослідження «професійно зорієнтовані завдання» i «прикладна задача».

Виклад основного матеріалу. У педагогічних дослідженнях наведено кілька визначень професійно зорієнтованих завдань. Так, Г. Дутка професійно зорієнтовані завдання розглядає як текстові завдання, фабули яких зорієнтовані на ту чи іншу сферу професійної діяльності, а їхні вирішення 
відшуковуються математичними засобами (Дутка, 2008: 178). Подібне визначення пропонують К. Рум'янцева й О. Вільчинська, які трактують професійно зорієнтовані математичні завдання як завдання, умова і вимога якого визначають собою модель деякої ситуації, що виникає у професійній діяльності, а дослідження цієї ситуації здійснюється засобами математики і сприяє професійному розвитку особистості фахівця (Рум'янцева, Вільчинська, 2016: 71).

У дослідженні Н. Самарук професійно орієнтовані завдання визначаються як завдання, що представляють абстрактну модель деякої реальної ситуації, що виникає у професійній діяльності і розв'язувана засобами математики, у фабулі якої закладена можливість варіювання умов, процедур і результатів (Самарук, 2007: 24).

У результаті проведеного аналізу окреслених визначень варто зробити висновок, що загальним для них $\epsilon$ виокремлення двох напрямів професійно зорієнтованих завдань: змістовного i процесуального. Перший напрям характеризує зміст поставленого завдання 3 позиції професійного наповнення. Воно реалізується крізь фабулу завдання, яка виникає в результаті конкретної ситуації, пов'язаної із професійною діяльністю, або моделює іiі. Прикладами таких завдань $€$ вирішення систем лінійних рівнянь у вирішенні задач на тему «Закон Кірхгофа» в електротехніці, рішення задач на кодування і декодування інформації 3 дисципліни «Теорія інформації» за допомогою стохастичних методів, вирішення оптимізаційних задач на визначення найкоротшого маршруту в мережі 3 дисципліни «Комп'ютерні мережі» (Головань, 2014: 37).

Другий напрям пов'язаний із методами, застосовуваними у вирішенні задачі. В окреслених визначеннях ідеться про те, що завдання відображає модель ситуації, що виникає у професійній діяльності, але вирішується воно математичними методами. Наприклад, завдання визначення ефективності алгоритму вирішується за допомогою логарифмічної функції.

Окреслені напрями сприяють формуванню професійних компетенцій студентів, однак вивчення математики має формувати в майбутніх фахівців і загальні компетенції. 3 огляду на це варто було б окреслити у визначенні професійно зорієнтованих завдань і третій напрям - розвивальний, який може реалізовуватися шляхом підвищення мотивації навчання крізь зміст завдання і методи його вирішення, розвивати особистісні якості студента: спостережливість, різні види мислення, пам'ять, увагу тощо. Отже, професійно зорієнтоване завдання розглядаємо як завдання, що відображає абстрактну модель деякої реальної ситуації, що виникає у професійній діяльності, яке вирішується математичними методами або методами, застосовуваними у професійній діяльності майбутніх фахівців, і сприяє розвитку особистості майбутнього фахівця.

У визначенні типу професійно зорієнтованого завдання будемо керуватися класифікацією, запропонованою в дослідженні Ю. Триус, яка виокремлює два основні типи завдань: перший вид - це завдання, у яких уживаються професійні поняття i терміни для надання математичним поняттям особливого значення; другий вид - це завдання, які ставлять студента в деяку професійну ситуацію, що вимагає застосування математичних методів. Завдання першого роду найчастіше використовуються як мотиваційні в побудові математичної моделі і викладу нового матеріалу. Завдання другого виду дозволяють розвивати професійне мислення студента, готувати його засобами математики до майбутньої професійної діяльності і підвищувати інтерес до занять безпосередньо математикою (Триус, 2005: 200).

Поняття «професійно зорієнтовані завдання» $\epsilon$ видовим стосовно більш загального поняття - «прикладна задача» як завдання, окреслене поза математикою та розв'язуване математичними засобами. Будь-яке професійно зорієнтоване завдання має прикладний характер, оскільки дозволяє вирішувати завдання, що виникають за межами математики, математичними методами. Варто відзначити також особливу властивість професійно зорієнтованих завдань: те саме завдання для різних категорій студентів може мати лише прикладний характер i професійно зорієнтований характер для інших.

Натомість комплекс професійно зорієнтованих завдань трактуємо як завдання, підібрані з певної теми будь-якого розділу математики, що охоплюють професійно значущий зміст у сфері майбутньої професійної діяльності. Для використання в освітньому процесі курсу математики комплексу професійно зорієнтованих завдань необхідно виконати такі кроки:

1) провести вибірку необхідного теоретичного матеріалу із предметної сфери математики (Фирсов, 2006: 8);

2) встановити різноманітні міжпредметні зв'язки між математикою і практичними додатками, що належать до сфери майбутньої професійної діяльності із предметної сфери спеціальних і загальнопрофесійних дисциплін.

Вирішення професійно зорієнтованих завдань різних типів сприяє опануванню студентами 
основних математичних понять у сукупності із професійними термінами і є основним засобом реалізації принципу професійної спрямованості в навчанні математики в закладах вищої освіти. Саме системне використання сукупності математичних понять спільно із професійними термінами дає можливість поглиблення професійної спрямованості в навчанні математики. Важливо відзначити, що коли студенти розв'язують професійно зорієнтовані завдання протягом усього курсу математики, то водночас вивчають математику i вчаться застосовувати набуті знання у власній майбутній професійній діяльності, що відповідає вимогам державних стандартів до математичної освіти у процесі професійної підготовки майбутніх фахівців.

Тому впровадження у зміст курсу математики комплексів професійно зорієнтованих завдань на всіх основних етапах навчання $\epsilon$ одним із результативних методів навчання дисципліни «Математика», що сприяє підвищенню якості професійної підготовки майбутніх фахівців.

Застосування професійно зорієнтованих завдань на кожному етапі навчання виконує певну функцію:

- носій нових професійно значущих знань i способів дій на етапі вивчення нового матеріалу і як форма подачі професійно спрямованого змісту;

- засіб реалізації методу математичного моделювання, який $є$ одним із найважливіших методів навчання математики у ЗВО на всіх етапах навчання;

- мотивуюча функція, яка забезпечується математичною фабулою завдання, $є$ засобом розвитку пізнавального інтересу студентів, формування інтелектуальної гнучкості.

В організації процесу навчання математики у ЗВО виникає можливість застосування професійно зорієнтованих завдань протягом усього процесу навчання. У вивченні нового матеріалу професійно зорієнтовані завдання виступають в ролі мотивуючих завдань, у закріпленні рішення демонструє застосування математичних методів у професійній діяльності (Крилова, 2016: 22).

На етапі позааудиторної діяльності професійно зорієнтовані завдання виступають як частина завдання, яке вирішується після відпрацювання навику розв'язання завдань суто математичного змісту. Використання професійно зорієнтованих завдань на етапі контролю дозволяє діагностувати можливості студентів застосовувати отримані знання і вміння у професійній діяльності. Отже, систематичне використання професійно зорієнтованих завдань протягом усього процесу навчання дозволяє підтримувати на високому рівні навчальну мотивацію студентів, що досягається шляхом формування стійкого інтересу до дисципліни «Математика» і спецдисциплін, що вивчаються на спеціальності.

Особливе місце в реалізації принципу професійної спрямованості у ЗВО належить такій формі організації освітнього процесу, як розрахункова робота із застосуванням пакетів прикладних програм. Сучасна обчислювальна техніка і використовувані програми дозволяють розв'язувати суто математичні завдання без громіздких і обтяжливих обчислень (Рум'янцева, 2017: 99).

Необхідність виконання складних числових розрахунків і обчислень, що виникає у вирішенні безлічі професійних завдань, вимагає від фахівців не просто поверхневого вміння працювати із примітивним калькулятором, а й наявності складніших знань і навичок. Лабораторні роботи з математики мають специфіку - тут не потрібно дороге і складне устаткування, проводити якісь практичні експерименти. 3 іншого боку, виконання цих робіт пов'язано з необхідністю проводити складні і громіздкі розрахунки.

Досвід показує, що студенти рідко працюють із прикладними програмами, можливості навіть таких поширених програм, як Microsoft Excel, вони знають досить поверхнево. Тому під час виконання лабораторних робіт із математики студенти, крім закріплення теоретичних знань за відповідними розділами математики, ще й виробляють навички використання таких потужних програмних продуктів, як, наприклад, Microsoft Excel, MathCAD. Нам видається, що ключовим позитивним результатом правильно виконаної лабораторної роботи $є$ те, що студенти достатньою мірою опанували методи вирішення математичних задач.

Структура і зміст лабораторних робіт виконують такі функції:

- навчальну: засвоєння теоретичного матеріалу і математичних методів вирішення завдань, посилення математичної підготовки фахівця;

- розвивальну: розвиток дослідницьких навичок;

- виховну: виховання відповідальності, акуратності, уваги, уміння працювати самостійно та в команді;

- мотивуючу: розвиток пізнавального інтересу й інтересу до обраної спеціальності (Семеніхіна, 2014: 350).

В організації позааудиторної самостійної роботи принцип професійної спрямованості реалізується шляхом вирішення професійно зорієнтованих завдань і виконання професійно зорієнтованих проєктів як форми організації 
навчальної діяльності студентів щодо створення, дослідження i реалізації математичних моделей, які $є$ значущими у професійній діяльності майбутніх фахівців. Робота над проєктом сприяє формуванню і вдосконаленню професійно важливих якостей майбутнього фахівця. У межах дослідження виокремлюємо два види професійно зорієнтованих проєктів у системі професійно орієнтованого навчання математики: змістовні і процесуальні. Під змістовними проєктами розуміємо проєкти щодо реалізації математичних моделей на зміст суміжних спеціальних дисциплін. Процесуальні проєкти передбачають реалізацію побудованої математичної моделі методами, застосовуваними у професійній діяльності: готовими прикладними програмами або розробленням власного програмного продукту.

Професійно зорієнтовані проєкти в системі професійно орієнтованого навчання математики виконують такі функції:

- навчальну: засвоєння теоретичного матеріалу і математичних методів вирішення завдань, посилення математичної підготовки фахівця, засвоєння теоретичного матеріалу із суміжних дисциплін;

- розвивальну: розвиває дослідницькі навички, алгоритмічне мислення студентів, професійно важливі якості особистості майбутніх фахівців;
- виховну: виховує почуття відповідальності за результат діяльності, уміння працювати самостійно та в команді, формує професійну культуру майбутнього фахівця;

- мотивуючу: підвищує навчальну мотивацію студентів, розвиває пізнавальний інтерес до математики і суміжних спеціальних дисциплін.

Висновки. Отже, можемо стверджувати, що розширили обсяг поняття «професійно зорієнтоване завдання» шляхом залучення в нього не лише професійно зорієнтованих завдань, а й завдань для виконання лабораторних робіт із застосуванням персонального комп'ютера і професійно зорієнтованих проєктів для позааудиторної самостійної роботи, отримали можливість реалізовувати принцип професійної спрямованості у використанні різноманітних форм навчання із застосуванням різних методів навчання.

Систематичне виконання професійно зорієнтованих завдань на всіх етапах навчання математики, використання різноманітних форм організації освітнього процесу дають змогу підтримувати високий рівень навчальної мотивації студентів та домагатися водночас освоєння математичних знань і умінь, розширення уявлення студентів ЗВО щодо прикладного і професійного значення математики.

\section{СПИСОК ВИКОРИСТАНИХ ДЖЕРЕЛ}

1. Головань М. Математична компетентність: сутність та структура. Науковий вісник Східноєвропейського наиіонального університету. 2014. Вип. 1. С. 35-39.

2. Дутка Г. Фундаменталізація математичної освіти майбутніх економістів : монографія. Київ : УБС НБУ, 2008. $478 \mathrm{c}$.

3. Копетчук В. Методика формування професійної спрямованості навчання предметів математично-природничого циклу в медичному коледжі. Професійна педагогічна освіта: інноваиійні технології та методики : монографія / за ред. О. Дубасенюк. Житомир : Вид-во ЖДУ ім. І. Франка, 2009. С. 470-483.

4. Крилова Т. Концепція математичної підготовки студентів нематематичних спеціальностей вищої технічної школи. Дидактика математики: проблеми і дослідження. 2016. Вип. 25. С. 21-24.

5. Рум'янцева К. Міждисциплінарна спрямованість курсу вищої математики в економічній освіті. Фізико-математична освіта. 2017. Вип. 1 (11). С. 97-100.

6. Рум'янцева К., Вільчинська О. Використання та адаптація математичних методів і моделей у професійній підготовці майбутніх економістів : монографія. Вінниця : ПП «ТД «Едельвейс»», 2016. 204 с.

7. Самарук Н. Педагогічні умови забезпечення професійної спрямованості викладання математичних дисциплін. Нові технології навчання. 2007. Вип. 46. С. 22-26.

8. Семеніхіна О. Про реформування вищої педагогічної освіти в галузі математики. Педагогічні науки: теорія, історія, інноваиійні технологіï. 2014. Вип. 5 (39). С. 347-353.

9. Триус Ю. Комп’ютерно орієнтовані методичні системи навчання математики : монографія. Черкаси : БрамаУкраїна, 2005. 400 с.

10. Фирсов В. О прикладной ориентации курса математики. Математика в школе. 2006. № 7. С. 2-13.

\section{REFERENCES}

1. Holovan M. S. Matematychna kompetentnist: sutnist ta struktura [Mathematical competence: the key point and structure]. Scientific Bulletin of the Lesya Ukrainka Eastern-European National University. 2014. Vyp. 1. pp. 35-39. [In Ukrainian].

2. Dutka H. Ya. Fundamentalizatsiia matematychnoi osvity maibutnikh ekonomistiv: monohrafiia [Fundamentalization of mathematical education of future economists: monograph]. Kyiv: Banking University, 2008. 478 p. [In Ukrainian].

3. Kopetchuk V. A. Metodyka formuvannia profesiinoi spriamovanosti navchannia predmetiv matematychnopryrodnychoho tsyklu $\mathrm{v}$ medychnomu koledzhi [Methods of formation of professional orientation of teaching subjects 
of mathematical and natural cycle in medical college]. Professional pedagogical education: innovative technologies and methods: monograph. Zhytomyr: Ivan Franko Zhytomyr State University, 2009. pp. 470-483.

1. Profesiina pedahohichna osvita: innovatsiini tekhnolohii ta metodyky: monohrafiia / za red. O. A. Dubaseniuk. Zhytomyr : Vyd-vo ZhDU im. I. Franka, pp. 470-483. [In Ukrainian].

4. Krylova T. V. Kontseptsiia matematychnoi pidhotovky studentiv nematematychnykh spetsialnostei vyshchoi tekhnichnoi shkoly [The concept of mathematical training for students of non-mathematical specialties of higher technical schools]. Didactics of Mathematics: Problems and Investigations. 2016. Vyp. 25, pp. 21-24. [In Ukrainian].

5. Rumiantseva K. Ye. Mizhdystsyplinarna spriamovanist kursu vyshchoi matematyky v ekonomichnii osviti [Interdisciplinary orientation of the course of higher mathematics in economic education]. Physical and Mathematical Education 2017. Vyp. 1 (11). pp. 97-100.

6. Rumiantseva K. Ye., Vilchynska O. M. Vykorystannia ta adaptatsiia matematychnykh metodiv i modelei u profesiinii pidhotovtsi maibutnikh ekonomistiv: monohrafiia [The use and adaptation of mathematical methods and models in professional training of future economists: monograph]. Vinnytsya: Private enterprise trading house "Edelweiss and K", 2016. 204 s.

7. Samaruk N. M. Pedahohichni umovy zabezpechennia profesiinoi spriamovanosti vykladannia matematychnykh dystsyplin [Pedagogical conditions for providing the professional orientation in teaching of mathematical disciplines]. New Teaching Technologies: the scientific works collection of the Institute of Education Content Modernization. 2007. Vyp. 46. pp. 22-26.

8. Semenikhina O. V. Pro reformuvannia vyshchoi pedahohichnoi osvity $\mathrm{v}$ haluzi matematyky [On the reform of higher pedagogical education in the field of mathematics]. Pedagogical sciences: theory, history, innovative technologies. 2014. Vyp. 5 (39). pp. 347-353.

9. Tryus Yu. V. Kompiuterno-oriientovani metodychni systemy navchannia matematyky: monohrafiia [Computeroriented methodical systems of teaching mathematics: monograph]. Cherkasy: Brama-Ukraina, 2005. $400 \mathrm{p}$.

10. Firsov V. V. O prikladnoj orientacii kursa matematiki [On the applied orientation of the mathematics course]. Matematika v shkole. 2006. № 7. pp. 2-13. [in Russian]. 